\title{
Post COVID 19 and food pathways to sustainable transformation
}

\author{
Alison Blay-Palmer ${ }^{1} \cdot$ Rachel Carey $^{2} \cdot$ Elodie Valette $^{3} \cdot$ Matthew R. Sanderson $^{4}$
}

Accepted: 24 April 2020 / Published online: 18 May 2020

(c) Springer Nature B.V. 2020

The COVID 19 pandemic has demonstrated clearly that change can happen suddenly and dramatically, creating great uncertainty. Social distancing is the norm world-wide as we all work to 'flatten the curve'. The economy is crashing, and despite stabilizing attempts, continues to stagger. The combination of a pandemic with economies in decline around the world is increasing food insecurity across the globe (UN-FAO 2020).

But in uncertainty, new possibilities arise and new pathways open. Change creates the conditions for transformation. We now have an opportunity_perhaps a once-in-a-lifetime opportunity - to learn from past weaknesses and create food systems that are more healthy, sustainable, equitable and resilient.

Thinking ahead to post-COVID 19 food systems, it is important to ask, what are we learning about our level of preparedness? And what next steps are suggested by food system weaknesses at local, regional and global scales in the context of the international pandemic?

Lessons are already emerging from this crisis-and from the multiple innovative responses to it-about how to retool food systems toward sustainability and resilience. For example, numerous food providers and retailers have moved online (Open Food Network) and social enterprises are delivering fresh local food and backyard growing kits to vulnerable population groups.

This article is part of the Topical Collection: Agriculture, Food \& Covid-19

Alison Blay-Palmer

ablaypalmer@wlu.ca

Wilfrid Laurier University, Waterloo, Canada

2 School of Agriculture and Food, University of Melbourne, Melbourne, Australia

3 CIRAD, UMR ART-DEV, Univ Montpellier, Montpellier, France

4 Sociology, Anthropology, and Social Work, Kansas State University, Manhattan, KS, USA
Food systems though are complex and not as easy to address as a single focus disease threat, so offer multiple challenges and solutions at the same time. To navigate these complex and dynamic circumstances and amplify positive results, we need to consider:

1. Preparedness: We will need to do much more planning for disaster preparedness, and food systems need to be part of this. Local and regional food systems that have shorter supply chains are part of this preparedness, as is multi-scalar integration and governance that facilitates coherent coordination and cooperation in the system. We need to move away from a reliance on global supply chains-based on vertical-integration and corporatecontrolled inputs that threaten the livelihoods of farming families and smallholders-toward more diverse food systems that are sensitive to ecological and social places. Food system resilience is more likely to be fostered through a combination of first local, including informal, and regional and then global supply chains.

2. Systems thinking: Adopt a systems approach that places healthy, resilient, sustainable and equitable food systems at the heart of food policy (Lang et al. 2009). Reductionist, piece-meal thinking is harmful in a world of interconnected systems. We know that the current global food system degrades the land and soil, does not get food to more than 820 million food insecure people and provides unhealthy food to another 2 billion, contributes up to $37 \%$ of GHG gases to climate change and destroys biodiversity (IPBES 2019; HLPE 2019; IPES 2016; IPCC 2019). By integrating across these challenges through local food systems, we can tackle many problems at once and build local resilience by explicitly making agro-ecology and regenerative approaches to agriculture the production practices of choice wherever possible.

3. Strengthen social safety nets to ensure viability: Make strong commitments to small-holder and family farmers and small and medium enterprises along the food chain to ensure their viability for broader social resil- 
ience. This can be achieved in no small part through deliberate, secure demand from local and regional government institutions through, for example, stable public procurement (Foundational Economy Collective 2020). A universal basic income for everyone is part of this as we need to stabilize food supply and access (World Economic Forum 2020).

4. Centrality of knowledge sharing: Value story-telling and sharing as a way to capture good practices and lessons learned and build solidarity to amplify the voices of the communities that have needed solutions (Global Alliance for the Future of Food 2019). These ways of knowing need to be valued as science. We also need to actively include the voices of smallholder farmers, Indigenous peoples, women and youth.

5. Enable scale appropriate action: Allow decisions to be made as close to the community level as possible. Make scale appropriate choices in terms of technology and institutional governance to distribute resources and decision-making to the relevant scale. Work on City Region Food Systems and territoriality provide examples of approaches to build from. There is also the need to be inclusive, coherent and transparent across decision-making (UN-FAO 2018; HLPE 2019).

6. Enable fact-based decision-making: We need to gather evidence for what works. We need systems-based research to identify opportunities for what works, and why. This requires us to democratize information and see this as a public good, not something for sale.

7. Recognise the right to food: All levels of government should fulfil their obligations under international law to guarantee citizens right to food. Food system shocks and economic crises lead to rising food insecurity. Policy approaches to address hunger and food insecurity should be firmly grounded in recognition of the human right to food.

Together, these seven considerations must be enacted through multi-actor coordination across governance scales, from global bodies to national, regional and municipal governments, to local communities. This demands coherent and joined-up, coordinated policy (Rideout et al. 2007) and programmes so that pathways for sustainable transformation are founded on just, green, healthy and engaged food systems. Building on lessons and good practices that emerge from the COVID-19 pandemic, we can take steps now to allow more resilient adaptation to future crises and perhaps even mitigate such crises, which are sure to include complex systems linking agriculture, food, health, and climate.

\section{References}

Biovision Foundation for Ecological Development and Global Alliance for the Future of Food. 2019. Beacons of hope: Accelerating transformations to sustainable food systems. Global Alliance for the Future of Food. https://foodsystemstransform ations.org/wp-content/uploads/2019/08/BeaconsOfHope_Repor t_082019.pdf. Accessed 23 Apr 2020.

HLPE. 2019. Agroecological and other innovative approaches for sustainable agriculture and food systems that enhance food security and nutrition. A report by the High Level Panel of Experts on Food Security and Nutrition of the Committee on World Food Security, Rome.

IPCC. 2019. Summary for policymakers. In Climate change and land: An IPCC special report on climate change, desertification, land degradation, sustainable land management, food security, and greenhouse gas fluxes in terrestrial ecosystems (in press).

IPES-Food. 2016. From uniformity to diversity: a paradigm shift from industrial agriculture to diversifed agroecological systems. International Panel of Experts on Sustainable Food systems. www.ipes-food.org. Accessed 23 Apr 2020.

Foundational Economy Collective. 2020. What comes after the pandemic? A ten point platform for foundational renewal. https:// foundationaleconomy.com/english-covid-19-report/. Accessed 23 Apr 2020.

IPBES. 2019. Summary for policymakers of the global assessment report on biodiversity and ecosystem services of the Intergovernmental Science-Policy Platform on Biodiversity and Ecosystem Services. Bonn: IPBES Secretariat.

Lang, T., D. Barling, and M. Caraher. 2009. Food Policy: Integrating health, environment and society. Oxford: Oxford University Press.

Rideout, K., G. Riches, A. Ostry, D. Buckingham, and R. MacRae. 2007. Bringing home the right to food in Canada: Challenges and possibilities for achieving food security. Public Health Nutrition 10 (6): 566-573.

UN-FAO, RUAF and Laurier Centre for Sustainable Food Systems. 2018. City region food systems toolkit. https://www.fao.org/ in-action/food-for-cities-programme/toolkit/introduction/en/. Accessed 23 Apr 2020.

UN-Food and Agriculture Organization (FAO). 2020. Urban food systems and COVID-19: The role of cities and local governments in responding to the emergency. https://www.fao.org/3/ca8600en/ CA8600EN.pdf. Accessed 23 Apr 2020.

World Economic Forum. 2020. Universal basic income is the answer to the inequalities exposed by COVID-19. K. Wignaraja and B. Horvath. https://www.weforum.org/agenda/2020/04/covid-19-unive rsal-basic-income-social-inequality/. Accessed 23 Apr 232020.

Publisher's Note Springer Nature remains neutral with regard to jurisdictional claims in published maps and institutional affiliations.

Alison Blay-Palmer is the UNESCO Chair in Food Biodiversity and Sustainability Studies, the founding Director of the Laurier Centre for Sustainable Food Systems and a Professor in Geography and Environmental Studies at Wilfrid Laurier University. Alison has been a member of the Royal Society of Canada's College of New Scholars, Artists and Scientists since 2016.

Rachel Carey is a Lecturer in Food Systems at the University of Melbourne, Australia. She leads the Foodprint Melbourne research project, which is assessing the resilience of Melbourne's food system to shocks and stresses related to climate change and pandemic. Rachel is 
a member of the Melbourne Food Alliance and worked on the development of the City of Melbourne's food policy.

Elodie Valette is a geographer and a senior researcher at CIRAD (French Agricultural Research for Development). Her research focuses on territorial approaches for development, especially addressing the rural-urban linkages in France and in the Mediterranean. She is one of the coordinators of the URBAL research project, focusing on characterizing the impact of urban-driven food innovations on the sustainability of foods systems.

Matthew R. Sanderson is Randall C. Hill Distinguished Professor of Sociology, Anthropology, and Social Work at Kansas State University. $\mathrm{He}$ is Editor-in-Chief of Agriculture and Human Values. 